\title{
Dorota Sikora-Fernandez $\mid$ Rola władz lokalnych w zaspokajaniu potrzeb mieszkaniowych mieszkańców wspólnoty samorządowej - wybrane aspekty na przykładzie miasta Łodzi
}

The role of local governments in meeting inhabitants' housing needs: the case of Łódź (selected issues)

The social-economic and political transformation which took place in Poland in 1989 changed the way of shaping the housing policy, having transferred a considerable part of the responsibility for satisfying housing needs to local governments. The purpose of this article is to assess the housing policy conducted by the city of Łódź to address the housing needs of its inhabitants. The research carried out allows to evaluate the activities of the city authorities in this area negatively as it has not caused substantial improvement in housing situation in the city. The author also claims that bigger support is needed from the state for the implementation of local housing policies.

\begin{tabular}{r|l}
\hline DOI & https://doi.org/10.31268/StudiaBAS.2021.20 \\
\hline Słowa kluczowe & $\begin{array}{l}\text { polityka mieszkaniowa w Polsce, zasoby mieszkaniowe, mieszkania } \\
\text { komunalne, gminne mieszkalnictwo, potrzeby mieszkaniowe, Łódź }\end{array}$ \\
\hline Keywords & $\begin{array}{l}\text { housing policy in Poland, housing resources, communal housing, } \\
\text { municipal housing, housing needs, Łódź }\end{array}$ \\
\hline 0 autorce & $\begin{array}{l}\text { doktor nauk ekonomicznych, Wydział Zarządzania, Katedra } \\
\text { Zarządzania Miastem i Regionem, Uniwersytet Łódzki • } \\
凶 \text { dorota.sikora@uni.lodz.pl • ORCID 0000-0002-4425-0437 }\end{array}$ \\
\hline
\end{tabular}

Artykuł został udostępniony na licencji Creative Commons - Uznanie Autorstwa 3.0 Polska (CC BY 3.0 PL).

\section{Wstęp}

Zasoby mieszkaniowe należą do zasobu strategicznego dla danego terytorium. Warunkują też rozwój społeczno-gospodarczy zarówno w skali kraju, jak i w skali lokalnej. Deficyt mieszkań w Polsce na koniec 2019 r. wyniósł 641 tys., co oznacza, że prawie 1,7 mln osób nie miało własnego lokum ${ }^{1}$. Z danych Eurostatu wynika, że warunki mieszkaniowe w Polsce, mierzone m.in. takimi wskaźnikami, jak przeludnienie mieszkań, brak wyposażenia mieszkań w podstawową infrastrukturę techniczną czy walory funkcjonalne lokali, należą do najgorszych w Unii Europejskiej. W raporcie OECD na temat sytuacji mieszkaniowej w wybranych krajach wskazuje się, że pod względem liczby dostępnych mieszkań na 1000 mieszkańców Polska w 2018 r. zajmowała jedno z ostatnich miejsc (31. na 39.) ${ }^{2}$. Postępująca marginalizacja grup społecznych o najniższych dochodach i rozwarstwienie dochodowe społeczeństwa przełożyły się na powstanie widocznie gorszych obszarów mieszkaniowych, dzielnic, osiedli, zespołów budynków oraz

1 https://forsal.pl/artykuly/1457702,deficyt-mieszkaniowy-w-polsce-wciaz-brakuje-641-tys-lokali.html [dostęp: 25 czerwca 2021 r.].

2 OECD, Housing Stock and Construction, https://www.oecd.org/els/family/HM1-1-Housing-stock-and-construction.pdf [dostęp: 25 czerwca 2021 r.]. 
pojedynczych bloków w miastach ${ }^{3}$. Dodatkowo trudną sytuację pogłębiły negatywne trendy w planowaniu przestrzennym, wieloletnie niedoinwestowanie budynków mieszkalnych oraz czynsze, które były zbyt niskie w stosunku do kosztów utrzymania zasobów4 ${ }^{4}$.

Samorząd terytorialny jest jednym z kreatorów polityki mieszkaniowej, mającej na celu zapewnienie odpowiedniej jakości mieszkań oraz zintegrowanej z nimi infrastruktury mieszkaniowej. Jednym z zadań własnych gminy jest tworzenie warunków do zaspokajania potrzeb mieszkaniowych wspólnoty samorządowej. Gminy mają jednak dość ograniczone możliwości realizacji tego ustawowego obowiązku ze względu na brak wolnych mieszkań komunalnych oraz brak środków finansowych na budowę nowych lokali. Zasadniczo do obowiązków gminy w sferze mieszkaniowej należą m.in. działania w zakresie tworzenia zasobu mieszkaniowego w drodze budowy bądź nabywania budynków mieszkalnych, propagowanie tanich i łatwo dostępnych form budownictwa, wskazywanie lub udostępnianie gruntów pod budownictwo mieszkaniowe, wspieranie tworzenia infrastruktury towarzyszącej prywatnemu budownictwu mieszkaniowemu oraz określanie zasad zarządzania zasobami komunalnymi. Oznacza to, że gmina realizująca politykę mieszkaniową prowadzi działania zmierzające do poprawy sytuacji mieszkaniowej na swoim terenie.

Celem niniejszego opracowania jest analiza i ocena polityki mieszkaniowej prowadzonej przez miasto Łódź w kontekście zaspokajania potrzeb mieszkaniowych mieszkańców wspólnoty samorządowej. Realizacja tego celu wymaga odpowiedzi na następujące pytania badawcze:

- W jaki sposób działania władz lokalnych przekładają się na sytuację mieszkaniową w Łodzi, zwłaszcza w odniesieniu do dostępności mieszkań dla osób, których potrzeby mieszkaniowe nie są zaspokojone?

- W jakim stopniu są realizowane zapisy lokalnych dokumentów strategicznych dotyczących mieszkalnictwa?

- Jak wyglądają warunki mieszkaniowe w Łodzi?

W ramach artykułu przeprowadzono analizę dokumentów związanych z prowadzeniem polityki mieszkaniowej, w szczególności: Polityki mieszkaniowej Łodzi 2020+, wieloletniego programu gospodarowania zasobem mieszkaniowym Miasta Łodzi na lata 2016-2020 i wieloletniego programu gospodarowania zasobem mieszkaniowym Miasta Łodzi na lata 2021-2025 oraz Gminnego Programu Rewitalizacji miasta Łodzi 2026+. Zapisy dokumentów zestawiono z danymi statystycznymi uzyskanymi z Banku Danych Lokalnych Głównego Urzędu Statystycznego. Badania objęły lata 2009-20195. W ostatniej części artykułu zawarto wnioski z przeprowadzonych badań i rekomendacje w kwestii polityki mieszkaniowej Łodzi.

3 H. Zaniewska, M. Thiel, Mieszkaniowe obszary problemowe w Polsce, „Architecturae et Artibus” 2009, t. 1, nr 1, s. 99-107.

4 D. Sikora-Fernandez, Deprywacja mieszkaniowa w Polsce na podstawie wybranych czynników, "Space - Society - Economy" 2018, nr 26.

5 Główny Urząd Statystyczny w Polsce nie udostępnia późniejszych danych. 


\section{Samorząd terytorialny a zaspokajanie potrzeb mieszkaniowych}

Potrzeba schronienia jest jedną z podstawowych potrzeb człowieka. Dom okazuje się niezbędny do rozwoju społecznego i zawodowego. Mieszkanie pozwala człowiekowi być bardziej produktywnym, kreatywnym oraz innowacyjnym ${ }^{6}$. Zaspokajanie potrzeb mieszkaniowych jest równoznaczne ze stworzeniem określonych zasad funkcjonowania gospodarki mieszkaniowej, z wypracowaniem polityki mieszkaniowej wyznaczającej kierunki rozwoju budownictwa mieszkaniowego oraz z opracowaniem strategii zarządzania zasobem już istniejącym.

W wyniku transformacji społeczno-gospodarczej, która dokonała się w 1989 r., zaspokajanie potrzeb mieszkaniowych obywateli jest jednym z zadań własnych gmin. Zgodnie z zapisami ustawy o samorządzie gminnym ${ }^{7}$ gminy stały się odpowiedzialne zarówno za komunalne budownictwo mieszkaniowe, jak i za zarządzanie skomunalizowanym majątkiem, w tym zasobami mieszkaniowymi. Wymagało to nowego spojrzenia na politykę mieszkaniową. Działania mające doprowadzić do rozwoju sektora budownictwa mieszkaniowego, podjęte po 1989 r. na szczeblu zarówno centralnym (regulacje prawne), jak i lokalnym, były jednak wprowadzane bez wcześniejszej szerokiej analizy ich znaczenia oraz skutków dla całokształtu polityki mieszkaniowej. Próby stworzenia spójnego systemu pomocy państwa dla sektora mieszkalnictwa nie przyniosły oczekiwanych rezultatów ilościowych w postaci wzrostu liczby mieszkań oddawanych do użytku.

Z przejęciem zadań związanych z zaspokajaniem potrzeb mieszkaniowych wspólnoty samorządowej przez gminy nie powiązano działań w zakresie np. skorelowania polityki mieszkaniowej z polityką społeczną, wspierania budownictwa czynszowego czy choćby rozwijania mechanizmów solidarności społecznej w kwestii dbania o wspólną przestrzeń okołomieszkaniową. Wprost przeciwnie - działania zarówno państwa, jak i samorządów lokalnych koncentrowały się na promowaniu własności prywatnej. Na wykresie 1 przedstawiono stan budownictwa mieszkaniowego w latach 2009-2019 w podziale na poszczególne jego segmenty. Wyraźnie jest widoczna dominacja budownictwa indywidualnego oraz na sprzedaż i wynajem, przy niewielkim udziale pozostałych form, takich jak budownictwo komunalne, zakładowe, spółdzielcze i społeczne czynszowe.

Budownictwo mieszkaniowe należy do głównych czynników kształtujących standard mieszkaniowy ${ }^{8}$, który w ogólnym rozumieniu oznacza poziom zaspokojenia potrzeb mieszkaniowych uznany za społecznie właściwy ${ }^{9}$. Ekspert z dziedziny nieruchomości R. Cyran ${ }^{10}$ dzieli potrzeby mieszkaniowe na dwie grupy - pierwszą stanowią potrzeby o charakterze normatywnym, czyli te wynikające ze społecznie uznanych norm określających sposoby zaspokojenia tych potrzeb,

6 D. Sikora-Fernandez, Rola zasobów mieszkaniowych w kształtowaniu kapitału terytorialnego, "Studia KPZK" 2018, nr 184, s. 265-274.

7 Ustawa z dnia 8 marca 1990 r. o samorządzie gminnym (Dz.U. 2020, poz. 713, ze zm.).

8 R. Cyran, Zintegrowana polityka mieszkaniowa jako instrument rozwoju lokalnego, "Studia Ekonomiczne” 2013, $\mathrm{nr}$ 144, cz. 2 [Nowoczesne instrumenty polityki rozwoju lokalnego - zastosowanie i efekty w małych miastach, red. K. Heffner, M. Twardzik], s. 217-226, https://sbc.org.pl/Content/82394/SE_144.pdf [dostęp: 25 czerwca 2021 r.].

9 A. Andrzejewski, Polityka mieszkaniowa, Państwowe Wydawnictwo Ekonomiczne, Warszawa 1979.

10 R. Cyran, op. cit. 
Wykres 1. Udział poszczególnych segmentów budownictwa mieszkaniowego w Polsce w latach 2009-2019 (mieszkania oddane do użytku)

250000

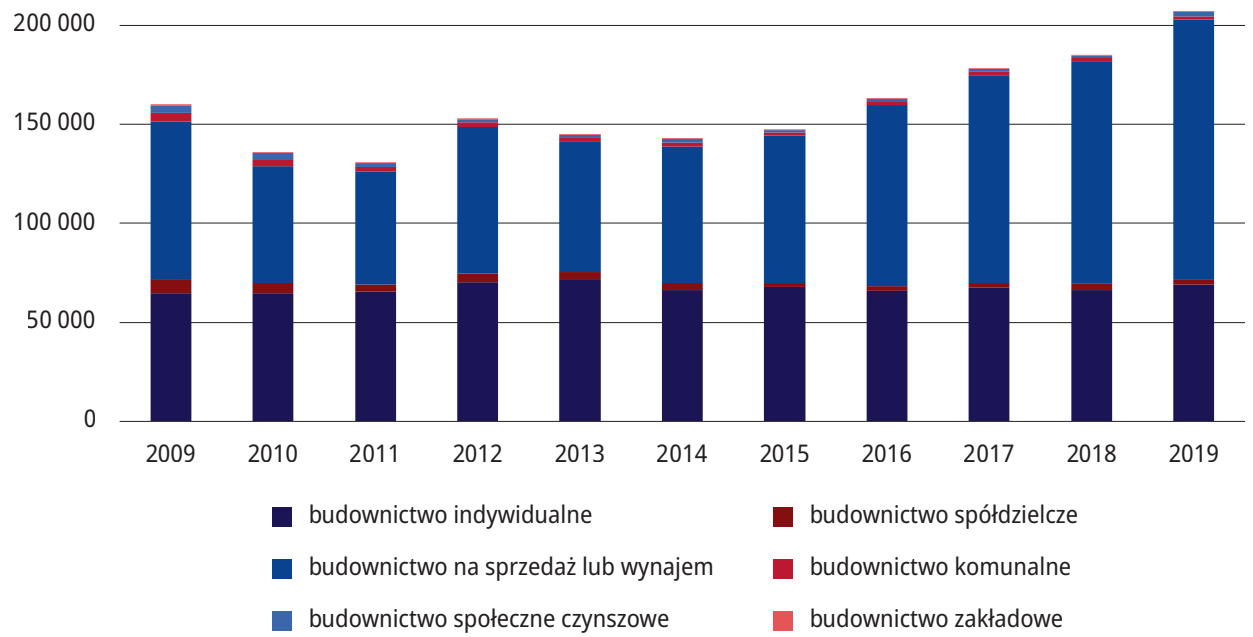

Źródło: Bank Danych Lokalnych Głównego Urzędu Statystycznego (BDL GUS), www.stat.gov.pl [dostęp: 16 stycznia 2021 r.].

natomiast w drugiej znajdują się potrzeby o charakterze rynkowym, tworzące efektywny popyt. Najprostszą metodą rozpoznawania potrzeb mieszkaniowych jest różnica pomiędzy liczbą gospodarstw domowych a liczbą mieszkań, skorygowana o liczbę mieszkań, które z powodu złego stanu technicznego powinny zostać wyburzone. Na potrzeby te wpływają m.in. aktualna sytuacja na rynku mieszkaniowym, sytuacja demograficzna oraz świadomość społeczna dotycząca mieszkalnictwa.

Cele lokalnej polityki mieszkaniowej powinny być w dużej mierze ukierunkowane na zmianę struktury zasobu mieszkaniowego. Zgodnie z tezą P. Lisa pozytywny „klimat inwestycyjny” bardzo sprzyja podmiotom prywatnym w budowaniu pożądanej liczby mieszkań, zatem istotne jest nie tyle wspieranie przez państwo i samorządy dostępności mieszkań w sensie ilościowym, ile poprawienie zdolności ludzi do nabycia lub najmu mieszkań ${ }^{11}$. Dla gmin oznacza to m.in. budowanie przewagi konkurencyjnej w celu przyciągnięcia dużych inwestorów pozytywnie wpływających na rynek pracy. Jest to możliwe dzięki powiązaniu wysokiej jakości zagospodarowania przestrzennego na obszarach zurbanizowanych z wysokiej jakości kapitałem ludzkim².

11 P. Lis, Zrównoważony rozwój rynków mieszkaniowych jako współczesne wyzwanie dla polityki mieszkaniowej państwa, „Problemy Polityki Społecznej. Studia i Dyskusje” 2017, nr 2(37), s. 53-71.

12 T. Markowski, Kapitał terytorialny jako cel zintegrowanego planowania rozwoju, "Mazowsze Studia Regionalne” 2016, nr 18, s. 111-119, https://www.mazowszestudiaregionalne.pl/images/pdf/18/msr_18_markowski_t.pdf [dostęp: 25 czerwca 2021 r.]. 
Z kolei w przypadku osób najsłabszych ekonomicznie niezbędne jest posiadanie odpowiedniego pod względem ilościowym i jakościowym zasobu mieszkań komunalnych (w tym na wynajem socjalny). Obecny deficyt tego typu lokali wynosi ponad 160 tys. ${ }^{13}$, a do jego obniżenia niezbędna jest pomoc państwa.

Nie ulega wątpliwości, że polityka mieszkaniowa zapewniająca odpowiednią dostępność lokali dla różnych grup społecznych nie tylko tworzy odpowiednie warunki do osiągania lepszych wyników gospodarczych, lecz także pozytywnie oddziałuje na sferę społeczną w miastach. Z zasobami mieszkaniowymi wiąże się wartość dodana w postaci wielu dóbr quasi-publicznych o charakterze materialnym i niematerialnym. Należą do nich m.in.: ład przestrzenny, doznania estetyczne, społeczny system wartości, tożsamość, kapitał społeczny, zaufanie do władz publicznych, trwałe relacje społeczne, poczucie sprawiedliwości społecznej itp. Korzyści te można uzyskać jedynie wówczas, gdy przy podejmowaniu mieszkaniowych decyzji inwestycyjnych będą uwzględnione kwestie zarówno mobilności i dostępu do zatrudnienia czy edukacji, jak i te związane z lokalizacją i zagospodarowaniem przestrzennym ${ }^{14}$. Brak dostępnych mieszkań stanowi istotną przeszkodę w zdobyciu i utrzymaniu pracy, szczególnie dla osób o niskich dochodach ${ }^{15}$.

Na mocy ustawy o samorządzie gminnym przekazano gminom do realizacji zadania związane z budownictwem mieszkaniowym, a zgodnie z zapisami ustawy o ochronie praw lokatorów ${ }^{16}$ nałożono na nie także obowiązek tworzenia warunków do zaspokajania potrzeb mieszkaniowych wspólnoty samorządowej. Aby gmina mogła spełnić te zadania, musi prowadzić skuteczną politykę mieszkaniową, skierowaną do szerokiej rzeszy odbiorców ${ }^{17}$. A zatem zarówno do obywateli najsłabszych ekonomicznie, jak i do pozostałych grup ludności, na tyle silnych ekonomicznie, że mogą pozyskać mieszkanie z wykorzystaniem środków własnych. W przypadku tych pierwszych rolą gminy powinno być dostarczanie im mieszkań przeznaczonych na wynajem socjalny i stosowanie instrumentów pomocowych w zakresie pozyskania i utrzymania własnego mieszkania. Działania gminy uwzględniające potrzeby drugiej grupy osób sprowadzają się do oferowania inwestorom komercyjnym gruntów pod budownictwo mieszkaniowe. Kluczowe staje się zatem połączenie polityki mieszkaniowej z gospodarką gruntami i polityką przestrzenną. Budownictwo mieszkaniowe to sektor w największym stopniu użytkujący tereny miejskie, więc może generować poważne koszty gospodarcze, społeczne i środowiskowe, jeśli jego cel zostanie zredukowany jedynie do wytworzenia zasobów fizycznych w sposób powodujący rozrastanie się przypadkowej formy miejskiej ${ }^{18}$. Należy wyraźnie podkreślić, że polityka mieszkaniowa

13 https://forsal.pl/nieruchomosci/mieszkania/artykuly/7528602,lepsze-18-000-gminnych-lokali-niz-mdm.html [dostęp: 25 czerwca 2021 r.].

14 D. Sikora-Fernandez, Rola zasobów...

15 B. Sard, M. Waller, Housing Strategies to Strengthen Welfare Policy and Support Working Families, Center on Urban \& Metropolitan Policy, The Brookings Institution, Washington 2002, https://www.brookings.edu/ wp-content/uploads/2016/06/sardwallerhousingwelfare.pdf [dostęp: 26 czerwca 2021 r.].

16 Ustawa z dnia 21 czerwca 2001 r. o ochronie praw lokatorów, mieszkaniowym zasobie gminy i o zmianie Kodeksu cywilnego (Dz.U. 2020, poz. 611, ze zm.).

17 D. Sikora-Fernandez, Rola zasobów...

18 I. Turok, Housing and the Urban Premium, "Habitat International” 2016, t. 54, cz. 3, s. 234-240, https://doi. org/10.1016/j.habitatint.2015.11.019. 
w gminach miejskich w dużym stopniu powinna być ukierunkowana na wspieranie procesów reurbanizacji i rewitalizacji obszarów centralnych, tzn. powinna być nastawiona na wykorzystywanie pod zabudowę mieszkaniową w pierwszej kolejności terenów już zagospodarowanych (typu brownfields), co w długim okresie będzie skutkować większą kontrolą nad rozlewaniem się zabudowy na tereny podmiejskie lub wręcz opanowaniem tego procesu. Problematyka roli polityki mieszkaniowej w procesach rewitalizacji jest o tyle ważna, że skala degradacji obszarów śródmiejskich jeszcze do niedawna była ogromna, a liczba ich mieszkańców w 2010 r. przewyższała liczbę osób zamieszkujących blokowiska, co potwierdzają wyniki badań Instytutu Rozwoju Miast ${ }^{19}$. Władze lokalne mogą zaspokajać potrzeby mieszkaniowe wspólnoty samorządowej także przez stymulowanie budownictwa mieszkaniowego za pomocą towarzystw budownictwa społecznego (TBS). Powiązana z polityką mieszkaniową jest także kwestia przeciwdziałania bezdomności i budowa schronisk oraz noclegowni dla osób bezdomnych.

Polityka mieszkaniowa gminy powinna być spójna z jej polityką rozwoju. Oznacza to, że jeżeli jednym z zadań władz lokalnych jest zapewnienie społeczności lokalnej dostępnych lokali mieszkalnych, to działania te nie mogą być sprzeczne z celami innych polityk sektorowych gminy. Przy formułowaniu polityki mieszkaniowej należy więc uwzględnić jej współzależności z innymi działaniami związanymi z zagospodarowaniem przestrzeni, w szczególności z problemami reurbanizacji, ubóstwa i wykluczenia społecznego, głównie w kontekście procesów rewitalizacji miast, ochrony środowiska czy ochrony zdrowia.

\section{Polityka mieszkaniowa w Łodzi i jej wpływ na sytuację mieszkaniową w mieście}

Łódź od lat boryka się z wieloma trudnościami w gospodarowaniu miejskim zasobem mieszkaniowym oraz w prowadzeniu skutecznej polityki mieszkaniowej. W dokumencie strategicznym Polityka mieszkaniowa Łodzi 2020+ stwierdzono, że miasto Łódź „prowadzi zintegrowaną politykę mieszkaniową wobec całego zasobu mieszkaniowego [...]"20. Polityka ta powinna uwzględniać działania w co najmniej trzech wymiarach: w tworzeniu warunków dla wszystkich mieszkańców miasta do pozyskania własnego mieszkania, niezależnie od formy własności pozyskanych zasobów, zapewnieniu odpowiedniej dostępności mieszkań dla różnych grup społecznych oraz utrzymaniu odpowiedniej jakości zasobów mieszkaniowych ${ }^{21}$. Istotą lokalnej polityki mieszkaniowej będzie zatem oddziaływanie konkretnych programów mieszkaniowych realizowanych przez samorząd na warunki mieszkaniowe ludności określonego obszaru terytorialnego ${ }^{22}$. Zgodnie z tak

19 W. Jarczewski, Skala degradacji miast w Polsce [w:] Rewitalizacja miast polskich - diagnoza, t. 8, red. Z. Ziobrowski, W. Jarczewski, Instytut Rozwoju Miast, Kraków 2010.

20 Polityka mieszkaniowa Łodzi 2020+, Łódź 2012, s. 3, https://uml.lodz.pl/files/public/user_upload/Polityka_ mieszkaniowa_Lodzi_2020_.pdf [dostęp: 25 czerwca 2021 r.].

21 P. Lis, Wahania cykliczne rynków mieszkaniowych. Aspekty teoretyczne i praktyczne, Wydawnictwo Adam Marszałek, Toruń 2012.

22 T. Markowski, D. Sikora-Fernandez, Publiczny wymiar zasobów mieszkaniowych, "Samorząd Terytorialny” 2019, nr 1-2, s. 36-48. 
sformułowanymi założeniami teoretycznymi i strategicznymi zadaniem samorządu terytorialnego powinny być konkretne działania w zakresie poprawy sytuacji mieszkaniowej, poparte odpowiednimi wskaźnikami pozwalającymi na jej monitorowanie. Łódź jest miastem, które przestało pełnić swoje pierwotne funkcje. Po upadku przemysłu włókienniczego oraz transformacji społeczno-gospodarczej i politycznej w 1989 r. obserwuje się stały spadek liczby ludności (wykres 2).

\section{Wykres 2. Liczba ludności w Łodzi w latach 1989-2019}

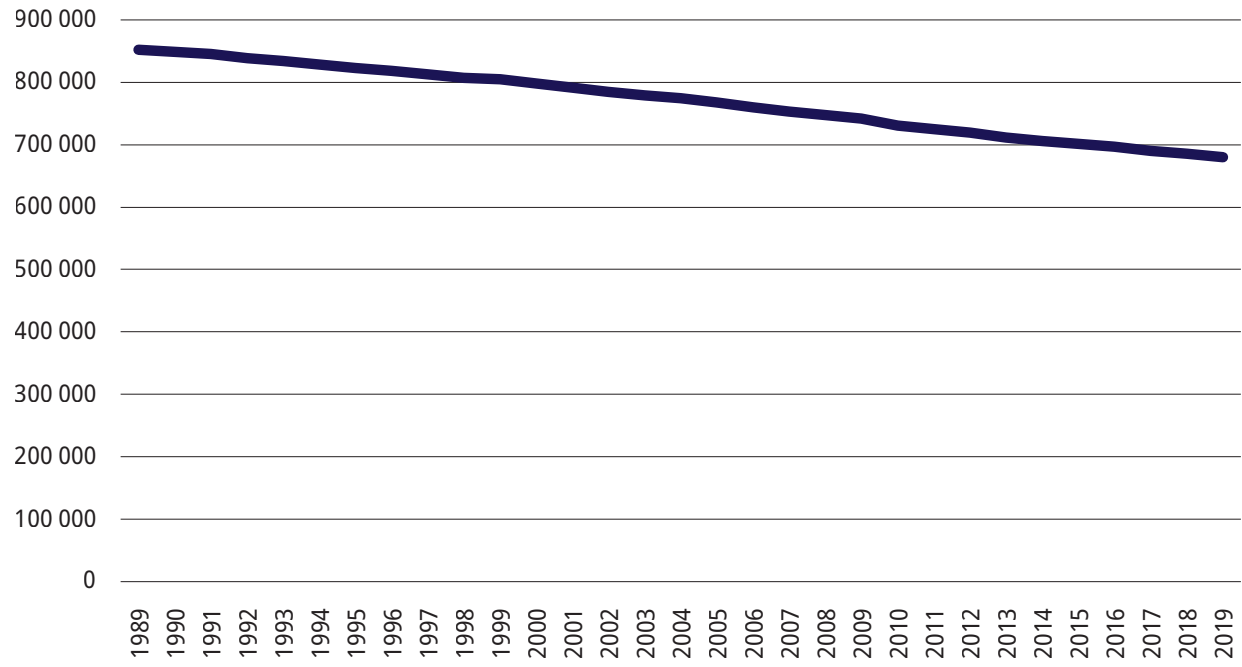

Źródło: BDL GUS, op. cit.

Sytuacja mieszkaniowa w Łodzi w zakresie liczby budowanych mieszkań w zasadzie nie odbiega od stanu ogólnokrajowego (por. wykres 1). Budownictwo mieszkaniowe w latach 2009-2019 opiera się prawie wyłącznie na mieszkaniach budowanych przez inwestorów indywidualnych lub na sprzedaż i wynajem. Mieszkań komunalnych oddano w badanym okresie łącznie 281, co stanowiło $1 \%$ wszystkich wybudowanych zasobów mieszkaniowych. Podobne wartości charakteryzują budownictwo spółdzielcze. Około 2\% stanowiły mieszkania TBS, prawie $14 \%$ to mieszkania indywidualne, a $82 \%$ to mieszkania przeznaczone na sprzedaż i wynajem.

Ostatniej diagnozy stanu zasobów mieszkaniowych w Łodzi dokonano przy okazji opracowania polityki mieszkaniowej w 2012 r. Wśród głównych problemów wymieniono wtedy:

- zbyt duży i nieefektywnie wykorzystywany zasób komunalny w stosunku do stopnia realizacji zadań w zakresie zapewniania mieszkań przeznaczonych do najmu socjalnego, tymczasowych i zamiennych,

- Zły stan techniczny zarówno budynków pozostających w dyspozycji miasta, jak i tych należących do wspólnot mieszkaniowych,

- brak odpowiedniego zasobu lokali na wynajem socjalny, lokali zamiennych i pomieszczeń tymczasowych w stosunku do istniejących na terenie miasta potrzeb, 
- zbyt niskie stawki czynszu za lokale mieszkalne,

- wysokie zaległości czynszowe przy jednoczesnym braku skutecznej ich windykacji,

- nieefektywny system prywatyzacji zasobów komunalnych,

- brak uporządkowania planistyczno-prawnego, w szczególności na obszarach z dużym udziałem komunalnego zasobu mieszkaniowego ${ }^{23}$.

Pomimo dostrzeżenia wyżej wymienionych problemów oraz podjęcia próby ich rozwiązania, co odzwierciedlały zapisy opracowanej i przyjętej w 2012 r. polityki mieszkaniowej, sytuacja po prawie 10 latach pozostaje bez zmian. Mieszkania na wynajem socjalny w 2019 r. stanowiły jedynie $0,06 \%$ wszystkich zasobów mieszkaniowych w Łodzi. Prognoza zawarta w wieloletnim programie gospodarowania zasobem mieszkaniowym Miasta Łodzi (WPGZMMŁ) na lata 2016$2020^{24}$ zakładała wzrost liczby lokali na wynajem socjalny do prawie 5 tys., ze stanu niecałych 2 tys. w 2015 r. Liczba ta nie zmieniła się znacząco, ponieważ w 2019 r. Łódź posiadała jedynie 2373 mieszkania przeznaczone na wynajem socjalny (wykres 3).

Wykres 3. Zmiany liczby mieszkań przeznaczonych na wynajem socjalny w Łodzi w latach 2009-2019

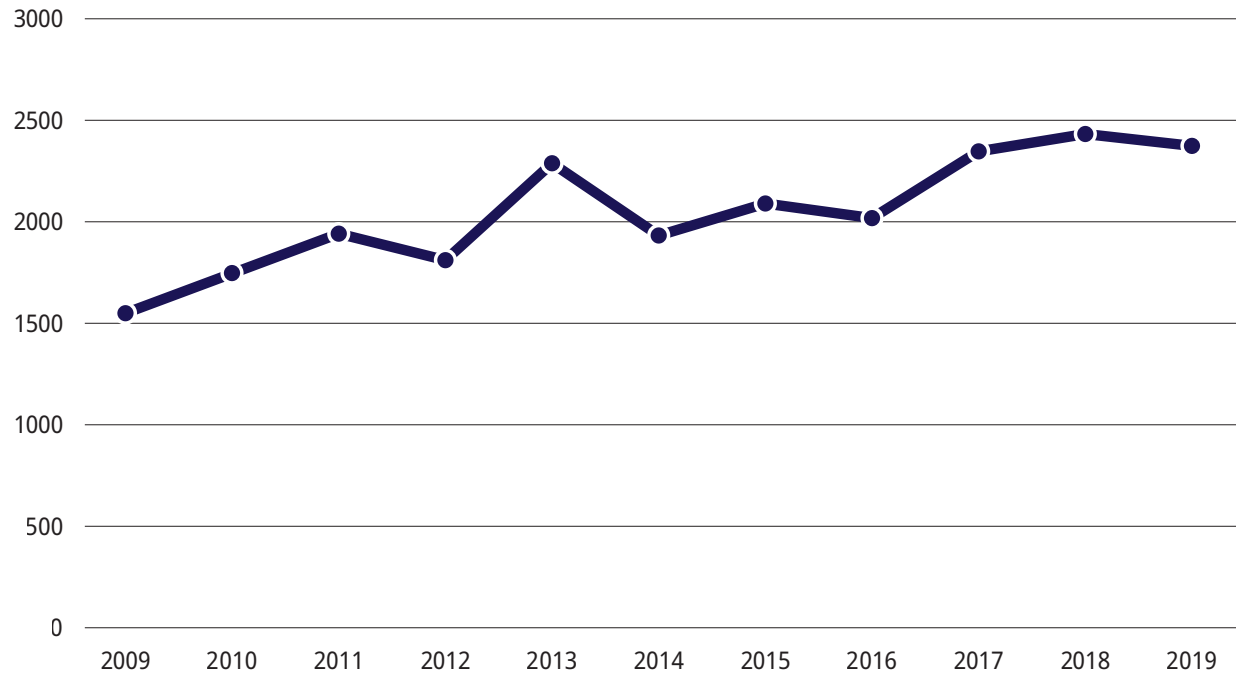

Źródło: BDL GUS, op. cit.

Zaległości czynszowe w komunalnym zasobie mieszkaniowym od wielu lat nie maleją (wykres 4).

23 Polityka mieszkaniowa...

24 Uchwała nr XXIV/572/16 Rady Miejskiej w Łodzi z dnia 3 lutego 2016 r. w sprawie przyjęcia wieloletniego programu gospodarowania mieszkaniowym zasobem Miasta Łodzi na lata 2016-2020, http://g.ekspert. infor.pl/p/_dane/akty_pdf/U72/2016/48/1187.pdf [dostęp: 25 czerwca 2021 r.]. 


\section{Wykres 4. Zaległości czynszowe w zasobach komunalnych w latach 2009-2018 w Łodzi (liczba zadłużonych mieszkań)}

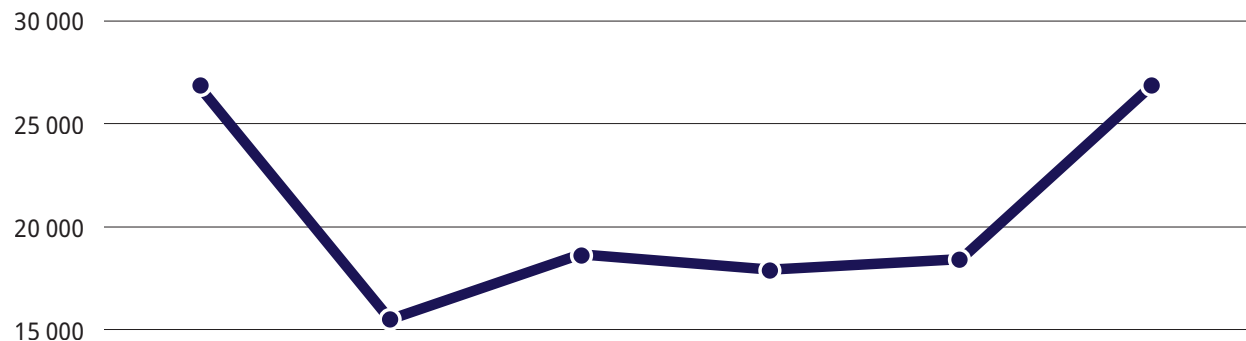

10000

5000

0

2009

2011

2013

2015

2016

2018

Źródło: BDL GUS, op. cit.

Problem ten wydaje się pogłębiać na skutek braku właściwego mechanizmu egzekwowania spłaty zaległości czynszowych. Nie stosuje się już eksmisji na bruk ani instrumentów pomocowych innych niż dodatki mieszkaniowe i mieszkania na wynajem socjalny (w deficycie). Brakuje także rozwiązań systemowych z zakresu polityki społecznej, co powoduje, że w najbliższym czasie nie należy się spodziewać zmniejszenia liczby zadłużonych mieszkań. Część najemców pozostaje zadłużona w wyniku zdarzeń losowych, część długów jest dziedziczona. Łódź, próbująca zmierzyć się z tym problemem, wprowadziła instrument umożliwiający odpracowanie przez dłużnika zaległości czynszowych przez wykonywanie prac porządkowych, remontowo-konserwatorskich oraz pomocniczych prac administracyjnych na rzecz miasta ${ }^{25}$. Warunkami skorzystania z tej pomocy są zadłużenie lokalu nie wyższe niż 10 tys. zł oraz dochód miesięczny nieprzekraczający 175\% najniższej emerytury w gospodarstwie jednoosobowym i 125\% - w gospodarstwie wieloosobowym. Od początku trwania programu (2015 r.) do końca 2019 r. zadłużeni najemcy mieszkań komunalnych odpracowali długi o wartości 2,5 mln zł²6.

Stan techniczny miejskich zasobów mieszkaniowych należy ocenić negatywnie. Ponad połowa budynków mieszkalnych, w których są zlokalizowane komunalne zasoby mieszkaniowe, to

25 E. Masierek, Miejska polityka mieszkaniowa jako niezbędne wsparcie dla procesów rewitalizacji obszarów śródmiejskich na przykładzie Łodzi, „Space - Society - Economy” 2016, nr 18 [Uwarunkowania polityki mieszkaniowej w Polsce i na Ukrainie, red. E. Masierek], s. 79-94, https://doi.org/10.18778/1733-3180.18.06.

26 https://samorzad.pap.pl/kategoria/jak-robia-inni/lodzianie-odpracowuja-dlugi-czynszowe [dostęp:

25 czerwca 2021 r.]. 
kamienice z lat 1901-1945. W przypadku ponad 5 tys. lokali mieszkalnych w nich zlokalizowanych zużycie techniczne wynosi powyżej 70\%. Łącznie prawie 9 tys. lokali z komunalnych zasobów mieszkaniowych wybudowanych w latach 1901-1990 jest w złym stanie technicznym ${ }^{27}$ - to $22 \%$ całego komunalnego zasobu miasta.

Wykres 5. Zużycie techniczne komunalnych zasobów mieszkaniowych w 2020 r. (w \%)

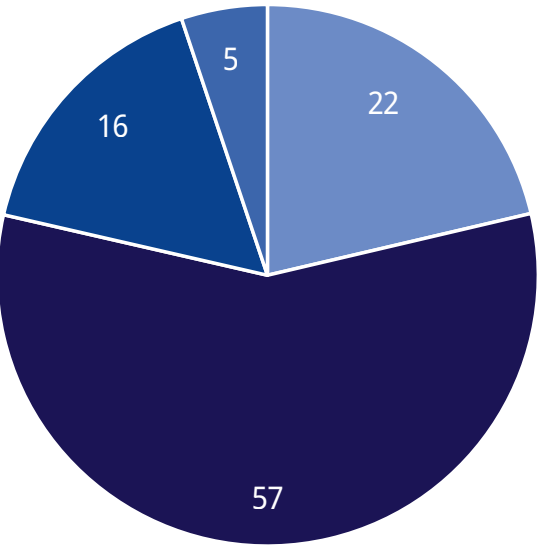

powyżej $70 \square$ प

Źródło: Wieloletni program gospodarowania zasobem mieszkaniowym Miasta Łodzi na lata 2021-2025, s. 6.

Budynki o zużyciu przekraczającym 70\% miasto zamierza przeznaczyć do rozbiórki lub - jeśli mają znaczną wartość zabytkową - do generalnego remontu, budynki o zużyciu 30-51\% mają zostać poddane remontom bieżącym i modernizacjom wraz z przebudową lub doposażeniem w instalacje, ewentualnie kompleksowym remontom, natomiast te o najniższym zużyciu - wyłącznie bieżącym remontom, jeśli takie są wymagane. Plany remontów i modernizacji będą układane w najbliższych latach zgodnie z przyjętymi priorytetami:

- usuwanie stanów zagrażających bezpieczeństwu mieszkańców i osób trzecich,

- zabezpieczanie budynków przed dalszą degradacją,

- likwidacja nieefektywnych źródeł ciepła,

- remonty dachów,

- wyposażenie mieszkań w instalacje sanitarne,

- remonty i modernizacje pustych lokali przeznaczonych do zasiedlenia.

Warunki mieszkaniowe są jednym z czynników decydujących o wyborze miejsca zamieszkania. Pomimo że od ponad 10 lat minimalnie zwiększa się powierzchnia użytkowa mieszkania oraz

27 Uchwała nr XL/1224/21 Rady Miejskiej w Łodzi z dnia 17 marca 2021 r. w sprawie przyjęcia wieloletniego programu gospodarowania komunalnym zasobem Miasta Łodzi na lata 2021-2025 (Dz. Urz. Woj. Łódz., poz. 1502), s. 5-6. 
przeciętna liczba osób na izbę, warunki mieszkaniowe w Łodzi można ocenić jako złe (tabela 1). Jedynie 89\% mieszkań w Łodzi w 2019 r. było wyposażonych w łazienkę, a 81\% - podłączonych do sieci ciepłowniczej ${ }^{28}$.

\section{Tabela 1. Podstawowe wskaźniki warunków mieszkaniowych w Łodzi w latach 2009-2019}

\begin{tabular}{|c|c|c|c|c|c|c|c|c|}
\hline \multirow[t]{2}{*}{ Rok } & \multicolumn{2}{|c|}{$\begin{array}{c}\text { Mieszkania na } 1000 \\
\text { mieszkańców }\end{array}$} & \multicolumn{2}{|c|}{$\begin{array}{l}\text { Przeciętna } \\
\text { powierzchnia } \\
\text { użytkowa } \\
\text { mieszkania } \\
\text { na } 1 \text { osobę }\end{array}$} & \multicolumn{2}{|c|}{$\begin{array}{c}\text { Przeciętna liczba izb } \\
\text { w mieszkaniu }\end{array}$} & \multicolumn{2}{|c|}{$\begin{array}{c}\text { Przeciętna liczba } \\
\text { osób na izbę }\end{array}$} \\
\hline & Polska & Łódź & Polska & Łódź & Polska & Łódź & Polska & Łódź \\
\hline 2009 & 348,5 & 454,8 & 24,6 & 24,3 & 3,71 & 3,08 & 0,77 & 0,71 \\
\hline 2010 & 349,6 & 469,3 & 25,3 & 25,0 & 3,81 & 3,07 & 0,75 & 0,69 \\
\hline 2011 & 352,6 & 474,7 & 25,6 & 25,4 & 3,81 & 3,07 & 0,74 & 0,69 \\
\hline 2012 & 356,1 & 482,3 & 25,9 & 25,8 & 3,81 & 3,07 & 0,74 & 0,67 \\
\hline 2013 & 359,9 & 489,4 & 26,3 & 26,3 & 3,82 & 3,08 & 0,73 & 0,66 \\
\hline 2014 & 363,4 & 495,6 & 26,7 & 26,7 & 3,82 & 3,08 & 0,72 & 0,66 \\
\hline 2015 & 367,3 & 502,2 & 27,0 & 27,1 & 3,82 & 3,08 & 0,71 & 0,65 \\
\hline 2016 & 371,3 & 508,2 & 27,4 & 27,5 & 3,82 & 3,08 & 0,70 & 0,64 \\
\hline 2017 & 375,7 & 516,1 & 27,8 & 28,0 & 3,82 & 3,08 & 0,70 & 0,63 \\
\hline 2018 & 380,5 & 523,9 & 28,2 & 28,5 & 3,82 & 3,08 & 0,69 & 0,62 \\
\hline 2019 & 385,9 & 534,1 & 28,7 & 29,1 & 3,82 & 3,08 & 0,68 & 0,61 \\
\hline
\end{tabular}

Źródło: BDL GUS, op. cit.

W założeniach wieloletniego programu gospodarowania zasobem mieszkaniowym Miasta Łodzi na lata 2021-2025 29 znalazło się znaczne zmniejszenie liczby komunalnych zasobów mieszkaniowych w 2025 r. (o prawie 4 tys. w stosunku do 2019 r.), będące następstwem sprzedaży lokali na rzecz dotychczasowych najemców, sprzedaży nieruchomości po przekwaterowaniu najemców, zmiany funkcji lokali mieszkalnych na niemieszkalne oraz rozbiórek budynków. Łódź sprzedaje lokale mieszkalne na zasadach określonych w uchwale Rady Miejskiej o zasadach sprzedaży mieszkań komunalnych ${ }^{30}$. Najemcom, którzy złożyli wnioski do końca 2018 r., przysługiwały następujące bonifikaty:

- 50\% dla budynków wzniesionych lub wyremontowanych po 31 grudnia 1989 r.,

- $70 \%$ dla budynków wzniesionych lub wyremontowanych od 1 stycznia 1946 r. do 31 grudnia 1989 r.,

- $80 \%$ dla budynków wzniesionych przed 1 stycznia 1946 r.

28 Bank Danych Lokalnych Głównego Urzędu Statystycznego, www.stat.gov.pl [dostęp: 16 stycznia 2021 r.].

29 Uchwała $\mathrm{nr}$ XL/1224/21...

30 Uchwała nr LXII/1615/17 Rady Miejskiej w Łodzi z dnia 13 grudnia 2017 r. zmieniająca uchwałę w sprawie określenia zasad sprzedaży, na rzecz najemców, samodzielnych lokali mieszkalnych i garaży oraz nieruchomości zabudowanych domami jednorodzinnymi (Dz. Urz. Woj. Łódz., poz. 7). 
Dodatkowo można było uzyskać $10 \%$ bonifikaty w przypadku wpłaty jednorazowej, kolejne 10\% w przypadku lokali przeznaczonych przez gminę do zamierzonej prywatyzacji oraz 5\% w przypadku jednoczesnej sprzedaży wszystkich lokali w budynku.

Pomimo stosowanych przez miasto zachęt w postaci bonifikat sprzedażowych liczba sprzedanych mieszkań komunalnych, po okresie nieznacznych wahań, spada w ostatnich latach (wykres 6).

\section{Wykres 6. Rozmiary prywatyzacji zasobów mieszkaniowych w latach 2009-2018}

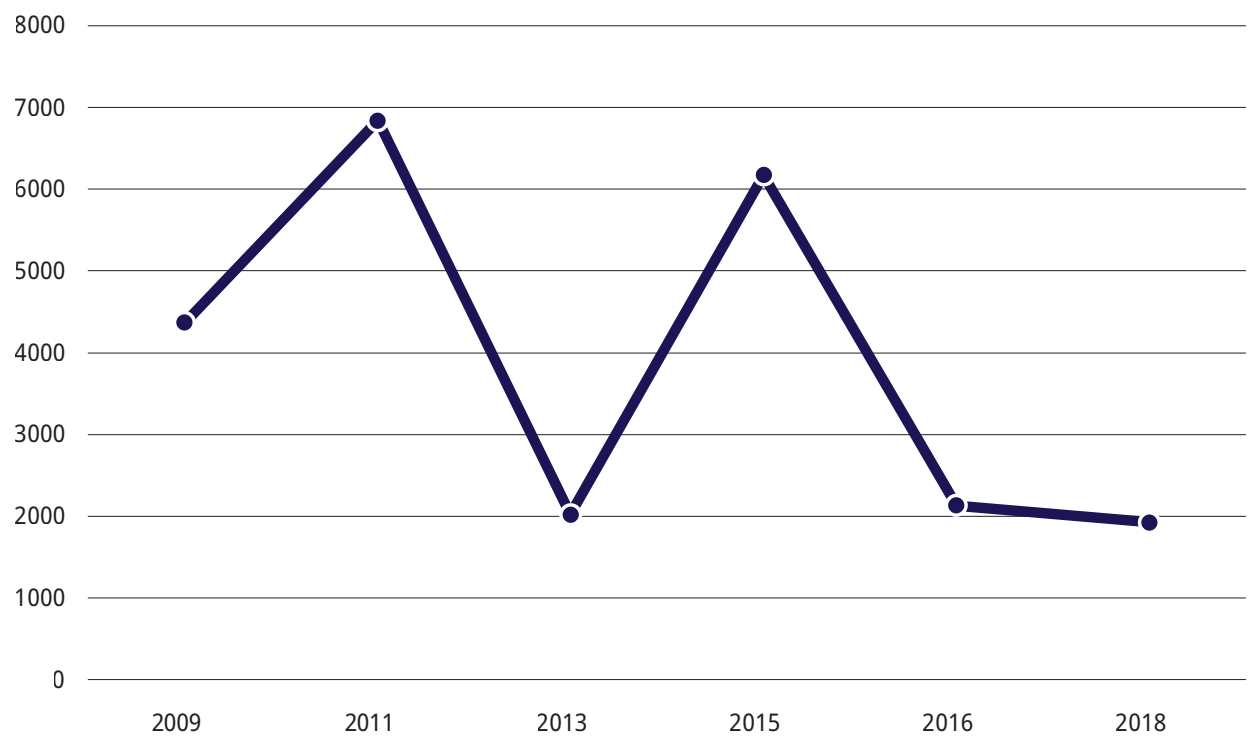

Źródło: BDL GUS, op. cit.

Na poziomie lokalnym do podstawowych celów polityki mieszkaniowej zaliczają się działania w kierunku zwiększania rzeczowych efektów budownictwa mieszkaniowego, poprawa stanu technicznego, a tym samym - jakości zasobów już istniejących oraz zapewnienie schronienia osobom najuboższym ${ }^{31}$. Realizacja polityki mieszkaniowej w Łodzi oparta jest na czterech celach operacyjnych:

- Cel 1 (C1). Miasto odnowionych kamienic,

- Cel 2 (C2). Miasto o rosnącym udziale mieszkań prywatnych,

- Cel 3 (C3). Miasto przyjazne lokatorom,

- Cel 4 (C4). Miasto bez eksmisji na bruk.

Realizacja wyżej wymienionych celów ma prowadzić do poprawy warunków mieszkaniowych i stworzenia rozwiązań sprzyjających rozwojowi budownictwa mieszkaniowego.

31 R. Cyran, op. cit. 
Polityka mieszkaniowa Łodzi jest w dużej mierze związana z rewitalizacją obszarową śródmieścia. W ramach C1 postanowiono zrealizować wiele działań, których efektem będzie m.in. zatrzymanie procesu degradacji zasobu mieszkaniowego, ze szczególnym uwzględnieniem dzielnic centralnych ${ }^{32}$. Wśród działań priorytetowych znajduje się program Miasto Kamienic ${ }^{33}$ (wzorowany zresztą na wrocławskim Programie 100 Kamienic). Jest to sztandarowy program miasta Łodzi realizowany od 2011 r., w ramach którego w starych kamienicach są wykonywane prace remontowe związane m.in. z termomodernizacją, wymianą stolarki okiennej i drzwiowej, modernizacją instalacji ciepłowniczej i wodno-kanalizacyjnej, odnowieniem elewacji oraz likwidacją wspólnych toalet ${ }^{34}$. Ponadto w wyremontowanych kamienicach rezygnuje się z istniejących tam mieszkań socjalnych i umieszcza się je poza strefą śródmiejską. Program jest finansowany ze środków własnych miasta, na podstawie mechanizmu polegającego na przeznaczaniu określonej puli środków finansowych pochodzących ze sprzedaży i z wynajmu nieruchomości komunalnych ${ }^{35}$. Łódź można nazwać jednym z największych kamieniczników w Polsce, w zasobach miasta pozostaje bowiem ok. 6 tys. kamienic, a ponad 1000 z nich znajduje się w stanie wymagającym natychmiastowej interwencji ${ }^{36}$, co stanowi ogromny problem z punktu widzenia realizacji założeń polityki mieszkaniowej. W latach 2011-2019 miasto przeznaczyło ponad $272 \mathrm{mln}$ zł na inwestycje remontowo-modernizacyjne w 226 budynkach, w tym w 193 budynkach mieszkalnych, dzięki czemu poprawił się ich stan techniczny. Ponadto od 2016 r. są prowadzone prace inwestycyjne w ramach programu Rewitalizacja Obszarowa Centrum Łodzi, w którym do 2020 r. łącznie wyremontowano 148 lokali mieszkalnych w 21 budynkach.

Rewitalizacja Obszarowa Centrum Łodzi jest obecnie sztandarowym programem władz miasta, mającym na celu przywrócenie świetności zdegradowanemu centrum. Program obejmuje 1783 ha, co stanowi ponad 6\% powierzchni miasta zamieszkiwane przez ponad 152 tys. osób. Przygotowany i uchwalony w 2016 r. Gminny Program Rewitalizacji miasta Łodzi $2026+{ }^{37}$ zakłada realizację celów wpisujących się w politykę mieszkaniową, do których należą:

- poprawa standardu technicznego budynków mieszkalnych,

- promocja powstawania przestrzeni publicznych i półpublicznych z udziałem mieszkańców,

- poprawa wyposażenia w infrastrukturę techniczną obszarów zamieszkania,

- rozwój społecznego budownictwa czynszowego.

32 Polityka mieszkaniowa...

33 Początkowo program nosił nazwę Mia100 Kamienic, jednak w 2014 r., po przekroczeniu liczby 100 wyremontowanych kamienic, nazwę zmieniono na Miasto Kamienic.

34 https://bip.uml.lodz.pl/urzad-miasta/programy-publikacje-raporty/rewitalizacja/program-miasto-kamienic/ [dostęp: 25 czerwca 2021 r.].

35 K. Janicka-Świerguła, Rewitalizacja dziedzictwa architektonicznego Łodzi w ramach programu "Mia100 Kamienic", "Czasopismo Inżynierii Lądowej, Środowiska i Architektury” 2017, t. 34, z. 64, s. 103-114, https://doi. org/10.7862/rb.2017.157.

36 https://regiony.rp.pl/finanse/inwestycje/22498-czy-premier-uratuje-lodzkie-kamienice [dostęp: 25 czerwca 2021 r.].

37 Załącznik do uchwały nr LXXII/1980/18 Rady Miejskiej w Łodzi z dnia 5 lipca 2018 r. Gminny Program Rewitalizacji miasta Łodzi 2026+, https://uml.lodz.pl/files/public/user_upload/Gminny_Program_Rewitalizacji. pdf [dostęp: 25 czerwca 2021 r.]. 
Działania te nie tylko dotyczą zasobów gminnych, lecz także są skierowane do właścicieli prywatnych i wspólnot mieszkaniowych, które miasto ma wspierać w zakresie poprawy stanu technicznego budynków oraz jakości przestrzeni wokół nich.

Realizacja celu C2 łódzkiej polityki mieszkaniowej ma opierać się na prywatyzacji części komunalnych zasobów przez koncentrację m.in. na całkowitym wyjściu gminy z małych wspólnot mieszkaniowych (obecnie do trzech lokali mieszkalnych), na finansowym wsparciu wykupu mieszkań komunalnych przez dotychczasowych najemców według zunifikowanych zasad oraz na programie sprzedaży działek miejskich pod zabudowę mieszkaniową w centrum miasta i na wynajem socjalny poza jego centrum. Celem miał być spadek liczby mieszkań komunalnych (bez uwzględnienia mieszkań na wynajem socjalny i pomieszczeń tymczasowych) do poziomu 15 tys. do końca 2020 r., czego jednak nie udało się osiągnąć. Na koniec 2020 r. mieszkaniowy zasób miasta wynosił ponad 43 tys. lokali (łącznie z najmem socjalnym i pomieszczeniami tymczasowymi, stanowiącymi jednak niewielki odsetek zasobów komunalnych).

Cel C3 zakłada efektywne zarządzanie komunalnymi zasobami mieszkaniowymi oraz stworzenie warunków do wynajmu mieszkań komunalnych dla osób o przeciętnych dochodach. Ocena skuteczności tych działań odbywa się na podstawie m.in. wskaźnika ściągalności czynszów na poziomie 97\%, a jego wysoka wartość jest efektem programu odpracowania długów czynszowych przez najemców mieszkań komunalnych. Cel C4, zakładający wzrost liczby mieszkań na wynajem socjalny i pomieszczeń tymczasowych do poziomu 10 tys. w 2020 r., nie został zrealizowany.

\section{Wnioski i rekomendacje}

Realizowana w Łodzi polityka mieszkaniowa nie przynosi zakładanych rezultatów. Sytuacja mieszkaniowa pogarsza się od wielu lat pomimo ambitnych zapisów kolejnych dokumentów strategicznych i wieloletnich programów gospodarowania zasobem mieszkaniowym. Wyrazem niezaspokojonych potrzeb mieszkaniowych w mieście są: brak zasobów komunalnych dobrej jakości, wieloletni czas oczekiwania na przydział mieszkania komunalnego, zły stan techniczny zasobów oraz znaczna liczba budynków, które powinny zostać wyburzone ze względu na zły stan techniczny i niespełnianie kryteriów ekonomicznych. Przyczyny takiej sytuacji należy upatrywać w historii miasta oraz przede wszystkim w kreowanej przez władze Łodzi na przestrzeni wielu lat polityce mieszkaniowej. Przyczyniła się ona m.in. do obecnej pogłębiającej się dekapitalizacji budynków mieszkalnych. Znaczny wzrost liczby mieszkań jest wyłącznie zasługą deweloperów. Można zatem postawić tezę, że miasto stosuje rynkowy model polityki mieszkaniowej, w której prawo do mieszkania nie jest dobrem quasi-publicznym, a potrzeby mieszkaniowe można zaspokoić wyłącznie we własnym zakresie, pod warunkiem posiadania odpowiedniego kapitału lub zdolności kredytowej.

Gospodarka mieszkaniowa wymaga podejmowania racjonalnych decyzji nie tylko na bieżąco, lecz także na przyszłość. Najlepszym instrumentem pomocnym w planowaniu kolejnych kroków jest długookresowy dokument strategiczny, który stanie się scenariuszem działań dla władz Łodzi zmierzających do poprawy mieszkalnictwa w mieście. W takiej strategii muszą być dokładnie określone etapy poprawy stanu mieszkalnictwa oraz jasno i konkretnie sformułowane cele pozwa- 
lające na wykorzystanie istniejących zasobów mieszkaniowych w gminie, przyspieszenie rozwoju budownictwa mieszkaniowego oraz koordynację działań w sferze mieszkalnictwa. Analiza zapisów Polityki mieszkaniowej Łodzi 2020+, wieloletniego programu gospodarowania zasobem mieszkaniowym Miasta Łodzi na lata 2016-2020 i wieloletniego programu gospodarowania zasobem mieszkaniowym Miasta Łodzi na lata 2021-2025 w zestawieniu z danymi statystycznymi pokazuje, że realizacja założonych celów w ustalonej perspektywie czasowej jest nierealna. Wieloletnie zaniedbania w kwestii mieszkalnictwa w Łodzi nie są możliwe do nadrobienia w ciągu kilku lat bez wsparcia ze strony budżetu państwa. Fiasko programu Mieszkanie Plus oraz brak długoterminowej strategii rozwoju mieszkalnictwa w całym kraju nie przyczyniają się do poprawy sytuacji.

O ile zwiększona prywatyzacja, a tym samym wychodzenie gminy ze wspólnot mieszkaniowych, jest właściwym rozwiązaniem, o tyle system bonifikat za nabycie mieszkania komunalnego przez dotychczasowego najemcę powinien być oparty również na mechanizmie renty miejskiej, czyli powinien uwzględniać lokalizację mieszkania i potencjalny dochód choćby z jego późniejszej sprzedaży, a nie tylko wiek budynku. Takie podejście pozwoliłoby myśleć o prywatyzacji zasobów mieszkaniowych w kontekście konkretnego planu ułatwienia obywatelom pozyskania własnego mieszkania. Tymczasem można odnieść wrażenie, że władze chcą pozbyć się poważnego problemu, jakim są budynki w najsłabszej kondycji technicznej, i przerzucić odpowiedzialność za zły stan zasobu mieszkaniowego na przyszłych właścicieli. Taka chaotyczna prywatyzacja może prowadzić do powstawania słabych ekonomicznie wspólnot mieszkaniowych, a tym samym pogłębiać i tak już niekorzystną sytuację mieszkaniową w Łodzi. Ponadto przerzucanie kosztów utrzymania zdegradowanych kamienic na dotychczasowych najemców, bez wnikliwej analizy ich sytuacji dochodowej, może stanowić pułapkę dla miasta w postaci kreowania większej grupy potencjalnych użytkowników mieszkań na wynajem socjalny w późniejszym czasie.

Budownictwo komunalne w Łodzi w ostatnich 10 latach jest na bardzo niskim poziomie. Zapisy polityki mieszkaniowej zakładające budowę 1,2 tys. mieszkań przeznaczonych na wynajem socjalny rocznie, tak aby w 2020 r. został osiągnięty poziom 10 tys., mocno odbiegały od rzeczywistości. Wydaje się, że właściwą ścieżką byłoby odejście od nadmiernej prywatyzacji mieszkań komunalnych na rzecz przeznaczania lokali w złym stanie na wynajem socjalny, przy jednoczesnym zwiększeniu liczby oddawanych mieszkań komunalnych.

Jak wspomniano w teoretycznej części niniejszego opracowania, skuteczna polityka mieszkaniowa powinna być powiązana z procesem rewitalizacji centrum, tak aby zapobiegać degradacji śródmieścia i ucieczce części mieszkańców na przedmieścia. Odnawianie śródmiejskich kamienic w ramach dwóch dużych programów (Miasto Kamienic i program Rewitalizacja Obszarowa Centrum Łodzi 2026+) zakłada jednak likwidację mieszkań przeznaczonych na wynajem socjalny w obszarze śródmiejskim. Dodatkowo znaczna część mieszkańców budynków objętych rewitalizacją nie chce do nich wrócić po zakończeniu prac modernizacyjnych. W 2018 r. przez łódzką prasę przetoczyła się dyskusja na ten temat - prawie 700 mieszkańców z 900 wyprowadzonych ze Śródmieścia na czas remontów nie zamierza wrócić do dawnych mieszkań38. Powstaje więc

38 https://www.money.pl/gospodarka/wiadomosci/artykul/lodz-rewitalizuje-centrum---tylko-mieszkac,145,0,2418577.html [dostęp: 25 czerwca 2021 r.]. 
wątpliwość co do zasadności prowadzonych działań w kontekście pojęcia „rewitalizacja”. Działania mające na celu wyprowadzenie najuboższych mieszkańców z centrum noszą znamiona gentryfikacji, krytykowanej w kontekście polityki przestrzennej i mieszkaniowej. Problem ten dotyka jednak wielu miast zmagających się z odnową obszarów centralnych i należy przyznać, że bez wsparcia w zakresie budowy mieszkań komunalnych i skutecznej polityki społecznej na szczeblu krajowym tych komplikacji nie da się uniknąć. W programach rewitalizacji kładzie się nacisk na odnowę m.in. budynków mieszkalnych i uwzględnia się rachunek ekonomiczny - czynsze za lokale komunalne muszą być więc na tyle niskie, żeby nie były nadmiernym obciążeniem dla przeciętnego najemcy, i na tyle wysokie, by można było pokryć koszty eksploatacji budynku. Z tego względu polityka mieszkaniowa musi obejmować działania i instrumenty odpowiadające specyfice lokalnych problemów i potrzeb mieszkaniowych ${ }^{39}$.

Brakuje w Łodzi czytelnego systemu aktualnych i kompletnych informacji o zasobach mieszkaniowych, niezbędnego do skutecznego zarządzania tkanką mieszkaniową. Kompleksowej diagnozy stanu mieszkalnictwa w mieście podjęto się w 2012 r. i była ona dokonana na potrzeby uchwalenia miejskiej polityki mieszkaniowej. Po prawie 10 latach zarządzanie zasobami mieszkaniowymi odbywa się na podstawie prognoz mających niewiele wspólnego z rzeczywistością, zawartych w wieloletnich programach gospodarowania. Dla zapewnienia skuteczności lokalnej polityki mieszkaniowej ważne jest jednak wyposażenie gmin w instrumenty adekwatne do poziomu zarządzania. Lokalna polityka mieszkaniowa musi być spójna z celami krajowej polityki mieszkaniowej i traktowana jako polityka wykonawcza. Jeśli polityka mieszkaniowa kraju w zasadzie nie istnieje lub jest realizowana bez szerszego, długookresowego planu (a tak się dzieje w Polsce), to gmina nie rozwiąże problemów mieszkaniowych, zwłaszcza występujących w tak dużej skali, jak w Łodzi.

Kompetencje formalne gminy w zakresie polityki mieszkaniowej są zawężone do jej własnych komunalnych zasobów. Właściwie rozumiane pojęcie lokalnej polityki mieszkaniowej należałoby jednak odnosić do wszystkich zasobów mieszkaniowych znajdujących się na terenie gminy, na które samorząd może potencjalnie wpływać za pomocą odpowiednio dobranych instrumentów, np. przez oddziaływanie na zachowania użytkowników mieszkań różnych typów. W związku z powyższym lokalna polityka mieszkaniowa nie powinna być zawężana tylko do zasobów mieszkaniowych należących do gminy (jak to z reguły jest obecnie).

\section{Bibliografia}

Andrzejewski A., Polityka mieszkaniowa, Państwowe Wydawnictwo Ekonomiczne, Warszawa 1979.

Cyran R., Zintegrowana polityka mieszkaniowa jako instrument rozwoju lokalnego, "Studia Ekonomiczne” 2013, nr 144, cz. 2 [Nowoczesne instrumenty polityki rozwoju lokalnego - zastosowanie i efekty w małych miastach, red. K. Heffner, M. Twardzik], https://sbc.org.pl/Content/82394/SE_144.pdf.

Janicka-Świerguła K., Rewitalizacja dziedzictwa architektonicznego Łodzi w ramach programu "Mia100 Kamienic”, "Czasopismo Inżynierii Lądowej, Środowiska i Architektury” 2017, t. 34, z. 64, https://doi.org/10.7862/rb.2017.157.

39 T. Markowski et al., Raport w sprawie polityki mieszkaniowej państwa, „Studia KPZK” 2018, t. 185, s. 1-78. 
Jarczewski W., Skala degradacji miast w Polsce [w:] Rewitalizacja miast polskich - diagnoza, t. 8, red. Z. Ziobrowski, W. Jarczewski, Instytut Rozwoju Miast, Kraków 2010.

Lis P., Wahania cykliczne rynków mieszkaniowych. Aspekty teoretyczne i praktyczne, Wydawnictwo Adam Marszałek, Toruń 2012.

Lis P., Zrównoważony rozwój rynków mieszkaniowych jako współczesne wyzwanie dla polityki mieszkaniowej państwa, „Problemy Polityki Społecznej. Studia i Dyskusje” 2017, nr 2(37).

Markowski T., Kapitał terytorialny jako cel zintegrowanego planowania rozwoju, „Mazowsze Studia Regionalne” 2016, nr 18, s. 111-119, https://www.mazowszestudiaregionalne.pl/images/pdf/18/msr_18_markowski_t.pdf. Markowski T. et al., Raport w sprawie polityki mieszkaniowej państwa, „Studia KPZK” 2018, t. 185.

Markowski T., Sikora-Fernandez D., Publiczny wymiar zasobów mieszkaniowych, „Samorząd Terytorialny” 2019, nr $1-2$.

Masierek E., Miejska polityka mieszkaniowa jako niezbędne wsparcie dla procesów rewitalizacji obszarów śródmiejskich na przykładzie Łodzi, „Space - Society - Economy” 2016, nr 18 [Uwarunkowania polityki mieszkaniowej w Polsce i na Ukrainie, red. E. Masierek], https://doi.org/10.18778/1733-3180.18.06.

Sard B., Waller M., Housing Strategies to Strengthen Welfare Policy and Support Working Families, Center on Urban \& Metropolitan Policy, The Brookings Institution, Washington 2002, https://www.brookings.edu/wp-content/ uploads/2016/06/sardwallerhousingwelfare.pdf.

Sikora-Fernandez D., Deprywacja mieszkaniowa w Polsce na podstawie wybranych czynników, "Space - Society Economy" 2018, nr 26.

Sikora-Fernandez D., Rola zasobów mieszkaniowych w kształtowaniu kapitału terytorialnego, "Studia KPZK" 2018, nr 184.

Turok I., Housing and the Urban Premium, „Habitat International” 2016, nr 54, cz. 3, https://doi.org/10.1016/j. habitatint.2015.11.019.

Zaniewska H., Thiel M., Mieszkaniowe obszary problemowe w Polsce, „Architecturae et Artibus” 2009, t. 1, nr 1.

\section{Uchwały, dokumenty}

OECD, Housing Stock and Construction, https://www.oecd.org/els/family/HM1-1-Housing-stock-and-construction. pdf.

Polityka mieszkaniowa Łodzi 2020+, Łódź 2012, https://uml.lodz.pl/files/public/user_upload/Polityka_mieszkaniowa_Lodzi_2020_.pdf.

Uchwała nr XXIV/572/16 Rady Miejskiej w Łodzi z dnia 3 lutego 2016 r. w sprawie przyjęcia wieloletniego programu gospodarowania mieszkaniowym zasobem Miasta Łodzi na lata 2016-2020 (Dz. Urz. Woj. Łódz., poz. 1187), http://g.ekspert.infor.pl/p/_dane/akty_pdf/U72/2016/48/1187.pdf.

Uchwała nr XL/1224/21 Rady Miejskiej w Łodzi z dnia 17 marca 2021 r. w sprawie przyjęcia wieloletniego programu gospodarowania komunalnym zasobem Miasta Łodzi na lata 2021-2025 (Dz. Urz. Woj. Łódz., poz. 1502).

Uchwała nr LXII/1615/17 Rady Miejskiej w Łodzi z dnia 13 grudnia 2017 r. zmieniająca uchwałę w sprawie określenia zasad sprzedaży, na rzecz najemców, samodzielnych lokali mieszkalnych i garaży oraz nieruchomości zabudowanych domami jednorodzinnymi (Dz. Urz. Woj. Łódz., poz. 7).

Załącznik do uchwały nr LXXII/1980/18 Rady Miejskiej w Łodzi z dnia 5 lipca 2018 r. Gminny Program Rewitalizacji miasta Łodzi 2026+, https://uml.lodz.pl/files/public/user_upload/Gminny_Program_Rewitalizacji.pdf. 


\section{Akty prawne}

Ustawa z dnia 21 czerwca 2001 r. o ochronie praw lokatorów, mieszkaniowym zasobie gminy i o zmianie Kodeksu cywilnego (Dz.U. 2020, poz. 611, ze zm.).

Ustawa z dnia 8 marca 1990 r. o samorządzie gminnym (Dz.U. 2020, poz. 713, ze zm.).

\section{Strony internetowe}

https://bip.uml.lodz.pl/urzad-miasta/programy-publikacje-raporty/rewitalizacja/program-miasto-kamienic/. https://forsal.pl/artykuly/1457702,deficyt-mieszkaniowy-w-polsce-wciaz-brakuje-641-tys-lokali.html. https://forsal.pl/nieruchomosci/mieszkania/artykuly/7528602,lepsze-18-000-gminnych-lokali-niz-mdm.html. https://regiony.rp.pl/finanse/inwestycje/22498-czy-premier-uratuje-lodzkie-kamienice. https://samorzad.pap.pl/kategoria/jak-robia-inni/lodzianie-odpracowuja-dlugi-czynszowe.

https://www.money.pl/gospodarka/wiadomosci/artykul/lodz-rewitalizuje-centrum---tylko-mieszkac,145,0,2418577.html. 